\section{Quality of life, social position and occupational groups in Brazil: evidence from a population-based survey}

\section{Qualidade de vida, posição social e grupos ocupacionais no Brasil: evidência de uma pesquisa de base populacional}

\section{Luisa Sorio Flor'}

Mônica Rodrigues Campos'

Josué Laguardia"

'Nacional Public Health School of Fundação Oswaldo Cruz - Rio de Janeiro (RJ), Brasil.

"Instituto de Comunicação e Informação Científica e Tecnológica em Saúde da Fundação Oswaldo Cruz - Rio de Janeiro (RJ), Brasil.

Corresponding author: Luisa Sorio Flor. Rua Dulce, 261/402, Tijuca, CEP: 20550-080, Rio de Janeiro RJ, Brasil. E-mail: luisa.sorio@gmail.com

Conflict of interests: nothing to declare.

\section{Abstract}

This study investigates whether occupation, variable that reflects social position, is associated with good quality of life among Brazilians. It is a cross-sectional study based on data obtained from a population-based survey carried out in Brazil in 2008. The sample composed of 12,423 Brazilians, older than 20 years. Physical and mental quality of life were both measured by SF-36 and scores were grouped in "above the mean" and "below the mean" to set binary outcomes. Logistic regression analysis was carried out to verify the impact of occupational position on the chances of better physical and mental quality of life, controlling it by socio-demographic and health variables. Results showed that Brazilians included on the labour market have better chances of a good physical and mental quality of life, even if controlled by other variables.

Keywords: Quality of life. Social class. Social conditions. Occupations. Health inequalities. Logistic models. Epidemiology. Social sciences. 


\section{Resumo}

Buscou-se avaliar as associações entre grupos ocupacionais, importante preditor da posição social, e uma boa qualidade de vida dos brasileiros. Trata-se de um estudo transversal baseado em dados obtidos em um survey de base populacional realizado no Brasil no ano de 2008. Foram analisados 12.423 brasileiros com idade superior a 20 anos. Os desfechos de qualidade de vida física e mental foram mensurados por meio dos componentes sumários do instrumento validado SF-36. Tanto a qualidade de vida física quanto a mental tiveram seus escores agrupados em "acima" $\mathrm{e}$ "abaixo da média" para configurar desfechos binários. Foi realizada regressão logística a fim de analisar o impacto da posição ocupacional nas chances de qualidade de vida física e mental acima da média, controlando por variáveis sociodemográficas e de saúde. Resultados apontaram que indivíduos inseridos no mercado de trabalho apresentam maiores chances de uma boa qualidade de vida física e mental mesmo controlando por outras variáveis.

Palavras-chave: Qualidade de vida. Classe social. Condições sociais. Ocupações. Desigualdades em saúde. Modelos logísticos. Epidemiologia. Ciências sociais.

\section{Introduction}

The term Quality of Life (QoL) refers to a multi-determined construct which can be applied to various fields of knowledge. The concept encompasses the distribution of both the citizenship assets - the assets and rights that a society, at a given time, believes to be essential - as well as the collective assets with implications for social welfare. Thus, the citizenship assets and the equality degree, which characterize the distribution between layers of the population, constitute the main concern of the studies focused on the QoL issue and eventually contribute to the understanding of the effects of the social system in the elements of this quality, including, health ${ }^{1}$.

The health-illness dimension, as a subset of the QoL concept, shall be understood as an articulated process with other social determinants structuring the urban space and delimitating the QoL contours in a space cut out from social inequalities. According to Fleck et al. ${ }^{2}$, QoL is a concept introduced to the human and biological sciences in order to humanize medicine and sciences alike by overcoming the biomedical model, the definition of health by the World Health Organization (WHO) and the approach to health promotion, which gives visibility to the interface between social conditions, QoL and health, reflecting the main objective of the social medicine classics ${ }^{1,3}$.

In this context of promoting health, medical practice, which previously focused only on diagnosis and treatment, begins to give importance to parameters broader than decrease in mortality or increase in life expectancy ${ }^{2}$. In this new paradigm, objective clinical measures join subjective individual perception indicators, as is the case of QoL ${ }^{4}$. The epidemiological and demographic transitions in the society, which led to a profile characterized by diseases and non-transmissible aggravations and by an increase in life expectancy, have contributed to the introduction of construct in the field of health, demanding actions to 
evaluate new elements which would influence QoL. Studies on QoL and its association to health are relatively new, but of growing significance in the last two decades. Great part of them had for objective the definition of the term and the presentations of the measuring tools for the $\mathrm{QoL}^{3}$.

However, to avoid ambiguity and to distinguish between QoL, in its broader sense, and its specific usages in health and clinical studies, the term Health Related Quality of Life (HRQoL) is often used. The HRQoL is a reflex of how individuals perceive and react to their health status and to other non-medical aspects of their lives. Also, the HRQoL refers to the physical, psychological and social domains of health in the cultural context and the systems of values in relation to one's goals, expectancies and worries ${ }^{3,5,6}$. Thus, the way individuals assess their health depends on the expectancy created on what is optimal health. These expectancies vary, however, according to several factors, among them, the socio-economic position and cultural issues, which may lead to different ways of perceiving their own health/QoL.

Authors like Paim ${ }^{7}$ and Castellanos ${ }^{8}$ emphasize the importance of social space in studies regarding the health-illness process and argue that, as this process is understood in terms of the individual's social position within the social space and the relationships arising therefrom, the study of this space is made fundamental. Regarding this perspective, many theoretical models were created to explain this relation between social position and the outcomes of health and quality of life ${ }^{9}$.

An individual's social position is defined by a combination of various aspects, including, income, education, occupation and life style. Each one of these elements, individually or combined, can exert both positive and negative influence on health conditions. Studies have shown that, regardless of the social markers or the health indicators used, there is a universal tendency for those who are socially best positioned to experience better health and
QoL conditions ${ }^{9}$. The Black Report, from 1980 , had an important role in spreading the importance of social status in health inequalities. The findings indicate there are significant disparities among the many social classes, which affect health indicators, such as birth weight, blood pressure or the risk of contracting serious illnesses ${ }^{10}$.

Castellanos $^{8}$ explains that the way of life to which individuals are subjected is a result of their positioning within the social organizational patterns, which is a consequence of the production and organization of the society. These facets interact among each other and ultimately determine the access of individuals to life assets, housing, leisure, sanitation, food, education, among others. Such finding opens up a whole new study field in health, social studies and sociology, in order to understand, as best as possible, the way in which social conditions relate to health and to the QoL. Assessing the populational health situation allows establishing the levels of comparison between groups, detecting injustices concerning health conditions, for different pathologies, geographical areas, social conditions, economic conditions or even conditions related to gender and age.

Thus, given that QoL is a multidetermined event, which greatly reflects on the life condition and health in the studied population, the objective of this study was to determine the magnitude and direction of the existing associations between socioeconomic positions and other socio-demographic and health characteristics, and the chances of a better physical and health QoL from the profile description and patterns of QoL score distribution (Short Form-36 SF-36 v2 in Portuguese) from a random sample of households in Brazil in 2008.

\section{Methodology}

\section{Study source}

The study data are from the Social Inequities Dimensions Research (PDSD), cross-sectional analytical data study 
conducted in 2008, coordinated by the University Research Institute of Rio de Janeiro (IUPERJ) with the participation of researchers of other academic institutions of teaching and research. This research was based on the Standard of Living Survey (PPV) of the Brazilian Institute of Geography and Statistics (IBGE), conducted between 1996 and 1997 in the southeastern and northern regions of the country, and sought to interview the heads of households and their spouses, both over 20 years of age, to produce updated information on the various dimensions of social inequalities and to comprehend the mechanism of production and reproduction of inequality throughout life. In the second semester of 2008, a the survey of data through a population-based household inquiry was conducted, whose sample design has been characterized by a stratified sample consisting of 1,374 census sectors (primary sampling units) and 8,048 permanent private households (secondary sampling units) in common or not special sectors, including favelas, in both urban and rural areas from all Brazilian regions ${ }^{11}$. In the end, 12,423 heads of households and spouses were interviewed. About $20 \%$ of primary residences were replaced by others, mainly due to the negative or the impossibility of one of the partners to receive the interviewer. In the instrument used in the PDSD, there were questions about education, health, work, housing, discrimination, perception of justice, among others.

\section{Outcome variable: quality of life}

As previously mentioned, the HRQoL, a segment of the QoL, refers to health aspects which are valued by people and overcome the components of general QoL ${ }^{12}$. Thus, despite a subjective condition, HRQoL measures are used many times as a proxy of individual and populational health conditions. Various tools have emerged to measure the HRQoL, converting subjective measures into quantified objective data ${ }^{13}$.

There are two kinds of measures application fields in HRQoL, which can be classified as specific or generic. The specific instruments detect particularities in QoL as consequences of some diseases or health aggravations and therefore are assigned to groups with the same illness. They are useful in the evaluation of therapeutic modalities in clinical testing and/or to accompany the changes that evolve during treatment. However, they do not allow comparisons between groups in different settings. Alternatively, the generic instruments evaluate health conditions and are used to evaluate various possible applications to the different health conditions in distinct populations or diseases. They are multidimensional, have a wide range of usage and allow comparing of the QoL of healthy individuals with that of sick ones, or with that of those bearing the same disease though living in different social and cultural contexts. However, they are not sensible in the detection of particular and specific aspects of QoL, resulting from a certain pathology $y^{1,3,12,14}$.

Among the generic measure instruments of QoL, the SF-36 stands out. It was developed in the late 1980s in EUA and was used for this study. The SF-36 was translated and validated in Brazil to evaluate the QoL of patients with rheumatoid arthritis and has proven adequate to the Brazilian socio-economic and cultural conditions. Besides, being a short, versatile and easyto-understand instrument, it allows international results comparison, thus making it an attractive tool to be used in populational inquiries ${ }^{11}$.

In the event of this study, the QoL was measured through a standard quiz, translated into Portuguese as SF-36 v.2, in which there were questions related to the four weeks before the interview ${ }^{13}$. The instrument consists of 36 items or questions evaluating eight health domains (or dimensions): Functional Capacity - PF (performance in daily activities, such as taking care of oneself, getting dressed, bathing and climbing stairs); Physical Aspects (physical health impact on the performance in daily and/or professional activities); Physical 
Pain - BF (level of pain and the impact on performance in daily and/or professional activities), General Health Condition GH (subjective perception of the general health condition); Vitality - VT (subjective perception of the health condition); Social Aspects - SF (reflex of physical health condition in social activities); Emotional Aspects RE (reflex of the emotional conditions on performance in daily and/or professional activities); Mental Health - MH (mood and well-being scale). These domains are commonly analyzed as a whole, and are summarized in Physical Components (PCS) and Mental Components (MCS).

For the study, summary measures of physical (PCS) and mental (MCS) QoL were considered. These dimensions were assessed in a scale of 0 to 100,100 being the best possible health condition. These scores were, however, turned into normalized scores in relation to the American population, with a mean of 50 and a standard deviation of 10 . This way, every time a scale's mark is over 50 , the health condition is below average. For the multivariate logistic regression analysis, the cases were grouped in "over average" and "below average" in order to set a binary outcome.

\section{Exposure of interest: occupational hierarchy as a translation of social positions}

Given the vast relation that exists between social and health/QoL conditions, the division of society into strata or social groups - which evidence particular characteristics concerning life condition and conditions of being sick and dying is a reflex of the social conditions experienced by the individuals.

Despite the methodological impasses regarding the definition of class or social status, studies and discussions on the theme, in Brazil, allow the elaboration of classification proposals and guide the choosing of logical models, which best fulfill the objectives of each research. Researches based on the analysis of survey data seek to evaluate social positions with the objective of developing statistical analysis, although there is no consensus on what is the best way to do it $\mathrm{so}^{15}$. Although some studies, especially in the economic field, associate income to social class, the two terms cannot be considered synonyms. According to the sociological traditions, social classes must be guided by the occupational positions within productive units and the laboring markets. Pastore ${ }^{16}$ explains that the occupation of an individual has special prominence within the assigned criteria and stands as a powerful indicator of the individual's position in social space.

The occupational classifications reflect the status measures acquired from information related to the occupations. Each occupational stratum, within a particular classification, is characterized by its relative homogeneity in work and market situations. In the present study, the occupation variable was considered in the determination of the subjects' social position, and it has used the International Socioeconomic Index of Occupational Status (ISEI), developed by Ganzeboom, De Graaf and Treiman ${ }^{17}$ from the occupational codes of the International Standard Classification of Occupations (ISCO 88). It is but a scale created from the analysis of socio-economic characteristics of people inserted in a determined occupation, in general, education and income. In order to apply the ISEI to Brazilian reality, it was necessary to convert the occupation codes of the Brazilian Occupations Classification (CBO 2002) concerning the current occupation of the head of the household to classify the ISCO 88 and, thereafter, to the scale of Ganzeboom et al. ${ }^{17}$, in which the occupation is classified and grouped, leading to the 11 social strata described in Chart 1.

Although the classification proposed by Ganzeboom et al. ${ }^{17}$ allows distinction between rural and urban work and between manual and non-manual work (important information when analyzing the labor market), the authors make clear that it does not follow a perfect hierarchy. Therefore, following the 
Chart 1 - Ganzeboom et al. ${ }^{17}$ class scheme, occupational hierarchical groups and examples of occupations. Quadro 1 - Esquema de classes de Ganzeboom et al. ${ }^{17}$, grupos hierárquicos e exemplos de ocupações.

\begin{tabular}{|c|c|c|c|}
\hline Social classes & & Hierarchical groups & Included occupations \\
\hline $\begin{array}{c}\text { Professional and } \\
\text { high-level managers }\end{array}$ & I & 1 & $\begin{array}{l}\text { Judge, Engineer, Director } \\
\text { of companies, etc. }\end{array}$ \\
\hline $\begin{array}{l}\text { Professional and } \\
\text { low-level managers }\end{array}$ & II & 2 & $\begin{array}{l}\text { Accountant, } \\
\text { manager, etc. }\end{array}$ \\
\hline Routine non-manual workers & Illa & 2 & $\begin{array}{c}\text { Secretary office, } \\
\text { administrative assistant, etc. }\end{array}$ \\
\hline $\begin{array}{l}\text { Routine non-manual workers - } \\
\text { sales and services }\end{array}$ & IIIb & 2 & $\begin{array}{l}\text { Waiter, receptionist, } \\
\text { sales clerk, etc. }\end{array}$ \\
\hline Self-employed with employees & IVa & 3 & Store owner, bakery owner etc. \\
\hline $\begin{array}{c}\text { Self-employed } \\
\text { without employees }\end{array}$ & $\mathrm{IVb}$ & 4 & $\begin{array}{l}\text { Street trader, proprietary } \\
\text { of commerce etc. }\end{array}$ \\
\hline Supervision of manual labor & V & 3 & Foreman, industrial mechanic etc. \\
\hline $\begin{array}{l}\text { Qualified manual } \\
\text { workers }\end{array}$ & $\mathrm{Vl}$ & 4 & $\begin{array}{l}\text { Auto mechanic, operator } \\
\text { of construction machinery etc. }\end{array}$ \\
\hline Unqualified manual workers & VIla & 5 & Mason, janitor, painter etc. \\
\hline Landowners without employees & IVc & 4 & Agriculturist, farmer, etc. \\
\hline $\begin{array}{l}\text { Rural } \\
\text { workers }\end{array}$ & VIllb & 5 & $\begin{array}{l}\text { Tiller, hoe worker, } \\
\text { cane cutter etc. }\end{array}$ \\
\hline- & - & 6 & Home workers, unemployed and retired \\
\hline
\end{tabular}

suggestions of Ribeiro ${ }^{15}$, the 11 strata were regrouped with the intention of improving the capturing of the existing hierarchy among occupational groups (Chart 1), characteristic of interest when wanted, for example, establishing those which would be the best and worst social positions within society and theirs relation with the health and life conditions experienced. Although the grouping, indicated by Ribeiro ${ }^{15}$, have not been applied to the scale of Ganzeboom et al. ${ }^{17}$ but to the model of Comparative Analysis of Social Mobility in Industrial Nations (CASMIN), groups have been paired up according to their employment relationships within each class. In the new grouping, class I formed the Hierarchical Group 1; classes II, IIIa and IIIb formed Group 2; classes IVa and
V formed Group 3; classes IVb, IVc and VI formed Group 4 and classes VIIa and VIIb formed Group 5. Group 6 was created exclusively for this research with the objective of gathering those interviewed, considered to be the non-economically active population (home workers, unemployed and retired people) who are not, usually, considered in occupational scales. The definition of such groups made possible to characterize the work situation of the interviewed, providing subsidies for data analysis.

\section{Associated factors: socio-demographic characteristics and health conditions}

Socio-demographic variables, adopted as possible determinants to a good life 
quality were: gender (male or female), age range (20 - 39, 40 - 64 and 65 years of age or more) and registered education level in years of completed study $(0 ; 1-4 ; 5-8$; $9-11, \geq 12$ years). Now, the variables chosen to represent health conditions were: morbities categorized according to the number of chronicle diseases and non-transmissible aggravations reported $(0 ; 1 ; 2 ; \geq 3)$ and smoking habit, either in the present or in the past (never smoked; has already smoked but quit and currently smokes).

\section{Data analysis}

In data analysis, descriptive statistics were used to draw occupational, sociodemographic, health and life quality profile of the Brazilian, using at all stages of the analysis the sample weights corresponding to the drawing of the stratified sample. The results have been exposed in charts with absolute and relative frequency measures for the variable categories. The average, median, minimum and maximum were presented for the continued summary measures of QoL of the SF-36 (PCS e MCS), according to occupational, socio-demographic and health variables. In order to verify the association between the exposition variables and the outcome of physical and mental QoL over the average, the $\chi^{2}$ test has been used, considering significant the variables, which presented p-value below 0.05 . Through this stage, it was possible to select the variables to be later on introduced in the multivariate model of logistic regression, chosen to try the adequate need of control of the multiple variables of confusion and usage, as variable response of a binary event. In this work, the model was used to identify the set of variables to best contribute to explain an over-the-average quality of life. The selection method used was Stepwise and the variables with $\mathrm{p}<0.10$ were included in the model. After the interactions, variables with $\mathrm{p}>0.10$ were eliminated, determining the logistic regression coefficients, the adjusted chance ratios and their respective trust interval at $95 \%$. Also, the predicted probabilities for each outcome (PCS > 50; MCS $>50$ ) were calculated according to the interest exposition (occupational group) in the final model. The cutoff point for the outcome proportion adopted was $50 \%$. The correct classification proportion between the positive and negative outcome as well as the total classification proportion were determined. The data were analyzed by the Statistical Package for the Social Sciences (SPSS) software, for Windows, version 17.0 (SPSS Inc., Chicago, USA).

The research was submitted to the Ethics in Research Committee, from the National School of Public Health Sergio Arouca (Comitê de Ética em Pesquisa da Escola Nacional de Saúde Pública Sergio Arouca) and its realization considered adequate to the human population (CEP: $\mathrm{n}^{\circ}$ 157/11).

\section{Results}

Among the participants, 5,255 (42.3\%) were men and nearly half of them between 40 and 64 years of age $(49.4 \%)$. As to the occupational group, it is noticeable that only $17 \%$ of the Brazilians are at the top of the hierarchy, represented by groups 1 and 2. About the years of study, $16.5 \%$ of the interviewed were classified as illiterate, nearly double of those have studied for 12 years or more. Most of the interviewed people have studied from 1 to 4 years (31.1\%). At least one chronic disease has been observed in $63.3 \%$ of the interviewed. Regarding smoking habits, more than half of the interviewed affirmed never to have smoked (55.7\%) (Table 1).

As for the QoL, men presented better physical health than women. Both the PCS and the MCS have presented lower scores for those of more advanced age who were interviewed, since the physical QoL is more affected by aging than mental QoL. Improvement in QoL is directly proportional to higher education, since the difference in physical QoL being more evident. Individuals with 12 or more years of study have presented an average score 
Table 1 - Descriptive analysis of socio-demographic and health characteristics by physical and mental quality of life components of SF-36 in "Pesquisa Dimensões Sociais das Desigualdades". Brazil, 2008.

Tabela 1 - Estatística descritiva das características demográficas e de saúde pelos componentes de qualidade de vida física e mental do SF-36 na Pesquisa Dimensões Sociais das Desigualdades. Brasil, 2008.

\begin{tabular}{|c|c|c|c|c|c|c|c|c|c|c|}
\hline \multirow{2}{*}{ Variables } & \multirow{2}{*}{$\mathrm{n}$} & \multirow{2}{*}{$\%$} & \multicolumn{4}{|c|}{ PCS } & \multicolumn{4}{|c|}{ MCS } \\
\hline & & & Mean & Min & Max & Median & Mean & Min & Max & Median \\
\hline \multicolumn{11}{|l|}{ Gender } \\
\hline Male & 5,255 & 42.3 & 50.7 & 2.4 & 69.6 & 54.8 & 52.9 & -1.1 & 76 & 55.3 \\
\hline Female & 7,168 & 57.7 & 48.3 & 5 & 74.7 & 51.3 & 49.7 & 2.5 & 76.9 & 52.3 \\
\hline \multicolumn{11}{|l|}{ Age (years) } \\
\hline $20-39$ & 3,973 & 32 & 54.3 & 12.7 & 74.7 & 57.1 & 52.1 & 2.5 & 75.4 & 54.5 \\
\hline $40-64$ & 6,132 & 49.4 & 48.9 & 5 & 71 & 51.9 & 50.8 & -1.1 & 76.9 & 53.4 \\
\hline$\geq 65$ & 2,318 & 18.7 & 41.8 & 2.4 & 63.9 & 42.1 & 50.1 & 5 & 76.5 & 52.6 \\
\hline \multicolumn{11}{|l|}{ Years of study } \\
\hline 0 & 1,904 & 16.5 & 43.2 & 2.4 & 68.4 & 43.5 & 48.1 & 7.2 & 76 & 50.1 \\
\hline $1-4$ & 3,592 & 31.1 & 47.5 & 6.3 & 71 & 50.2 & 50.7 & 5 & 74.9 & 53.2 \\
\hline $5-8$ & 2,529 & 21.9 & 50.9 & 5 & 74.7 & 54.5 & 51.2 & -1.1 & 76.5 & 53.8 \\
\hline $9-11$ & 2,408 & 20.9 & 53.1 & 11 & 69.8 & 56.3 & 52.8 & 2.5 & 74.4 & 55.3 \\
\hline$\geq 12$ & 1,109 & 9.6 & 53 & 18.9 & 70.7 & 56 & 53.1 & 3.6 & 73.6 & 55.3 \\
\hline \multicolumn{11}{|c|}{ Number of morbidities } \\
\hline 0 & 4,554 & 36.7 & 54.9 & 9.7 & 71 & 57.5 & 54 & 5.9 & 76.9 & 55.9 \\
\hline 1 & 3,035 & 24.4 & 50.3 & 8.6 & 74.7 & 53.4 & 52.1 & 2.5 & 74.4 & 54 \\
\hline 2 & 1,996 & 16.1 & 46.4 & 2.4 & 70.7 & 48.3 & 50.4 & 3.6 & 76.5 & 53 \\
\hline$\geq 3$ & 2,837 & 22.8 & 41.3 & 6.3 & 69.8 & 41.3 & 45.7 & -1.1 & 75.5 & 47.4 \\
\hline \multicolumn{11}{|l|}{ Smoking } \\
\hline Never smoked & 6,925 & 55.7 & 50.1 & 2.4 & 74.7 & 53.8 & 51.5 & 2.5 & 76.9 & 54.1 \\
\hline $\begin{array}{l}\text { Used to smoke } \\
\text { and stopped }\end{array}$ & 3,087 & 24.8 & 47.3 & 5 & 67.9 & 49.7 & 50.9 & -1.1 & 76.5 & 53.4 \\
\hline $\begin{array}{l}\text { Currently } \\
\text { smoke }\end{array}$ & 2,411 & 19.4 & 49.7 & 11.7 & 71 & 53.1 & 50 & 3.3 & 73.6 & 52.7 \\
\hline \multicolumn{11}{|c|}{ Occupational group } \\
\hline Group 1 & 475 & 3.8 & 54.3 & 16.3 & 69.6 & 56.8 & 53.6 & 3.6 & 69.1 & 55.5 \\
\hline Group 2 & 1,654 & 13.3 & 53.4 & 25.1 & 68.4 & 56.2 & 52.6 & 8.3 & 73.6 & 54.8 \\
\hline Group 3 & 646 & 5.2 & 52.5 & 13.9 & 67 & 56 & 52.8 & 1.7 & 75.5 & 54.9 \\
\hline Group 4 & 1,739 & 14 & 51.5 & 13.4 & 71 & 54.4 & 51.6 & 2.5 & 73.3 & 53.9 \\
\hline Group 5 & 1,656 & 13.3 & 52.8 & 8.6 & 67 & 56.3 & 53 & 7.8 & 73.1 & 55.2 \\
\hline Group 6 & 6,253 & 50.3 & 46 & 2.4 & 74.7 & 48.1 & 49.6 & -1.1 & 76.9 & 52.3 \\
\hline Total & 12,423 & 100 & 49.3 & 2.4 & 74.7 & 52.9 & 51.1 & -1.1 & 76.9 & 53.7 \\
\hline
\end{tabular}

PCS: physical quality of life; MCS: mental quality of life.

PCS: qualidade de vida física; $M C S$ : qualidade de vida mental. 
of PCS 53, while the illiterate presented a value around 43. The QoL decreased as a higher number of chronic diseases had been reported, with a variable average of 54.9 in the group with no diseases up to 41.3 in the group with three or more chronic diseases, and 54 to 45.7 for mental health. Individuals who have never smoked have a higher PCS and MCS average when compared to those who currently smoke (Table 1 ).

Regarding the exposition of interest variable, we realize that physical and mental health decrease as we head towards the less privileged occupational group. Those who are currently out of the labor market present worse physical and mental quality of life when compared to the other occupational groups, since the physical quality of life is more affected by one's position in social space. The PCS mean has varied from 54.3 (Group 1) to 46 (Group 6). Now, for the MCS, the average in Group 1 was 53.6 and, in Group 6 it was 49.6 (Table 1).

The bivariate analysis (Table 2) has shown that those in better occupation positions compose the group of above average physical and mental health $(\mathrm{p}=0.000)$ in greater number. Almost $80 \%$ of those present in Group 1 have presented QoL (physical and mental) score over 50 against those in Group 6, whose score is less than $50 \%$. It was observed that younger and fairly educated, healthier men, who have never smoked were also in majority when the PCS and MCS above average scores were considered.

A significant association was detected between the occupational group and the over-the-average PCS and MCS, which were being controlled by the other socio-demographic characteristics and health conditions in the multivariate logistic regression (Table 3). Economically active individuals present better chances of a good physical and mental QoL when compared to those of Group 6. Individuals, part of Group 1, had almost twice as many chances of an over-the-average physical health when compared to those of the last group. As it comes to mental health, the chance was 1.6 times bigger (Figure 1).

In the final model, an over-the-average physical QoL (PCS) was, yet, explained by age, education and by the number of aggravations. Young, well-educated and healthy younger individuals had bigger chances of reaching an above average physical health. Sex was not significant and smoking did not show significance in the subcategories (Table 3). The adjustment of the regression model to the PCS has shown a proportion of $74 \%$ of correct answers. Among the positive, the correct answers proportion was $\mathbf{8 0 . 3 \%}$ for the outcome and, among the negative, it was $65.4 \%$.

Good mental QoL was also explained by the variables: sex, age, education, number of aggravations and smoking. Older people, with higher educational level, healthy and who have never smoked, have higher chances of a MCS score over 50 (Table 3). The model used to measure the effects of the variables associated with mental health presented a proportion of a total $67.7 \%$ correct answers. Among the positive occurrences of the outcome, this proportion went from $85.4 \%$ and, among the negative, it was $37.8 \%$.

\section{Discussion}

Studies, which evaluated the relation of socio-demographic characteristics and health outcomes, and QoL, have been widely reported in the field of public health and epidemiology. These studies, however, vary according to the socio-economic and health measure evaluated. As to the social aspects, many of the authors have defended occupation as a powerful proxy of social position $^{16,18,19}$. Now, regarding health, the QoL indicators are commonly used as a measure capable of synthesizing the population's health situation ${ }^{18,20,21}$.

Given the results of the study, we can see the association between occupational position and a good physical and mental health, even after control by other socio-demographic and health variables. A significant 
Table 2 - Association between occupational groups, socio-demographic and health variables and physical and mental quality of life. "Pesquisa Dimensões Sociais das Desigualdades”, Brazil, 2008.

Tabela 2 - Associação entre grupo ocupacional, variáveis sociodemográficas e de saúde e qualidade de vida mental e física. Pesquisa Dimensões Sociais das Desigualdades, Brasil, 2008.

\begin{tabular}{|c|c|c|c|c|c|c|}
\hline \multirow{2}{*}{ Variables } & \multicolumn{3}{|c|}{$\mathrm{PCS}>$ mean $(50)$} & \multicolumn{3}{|c|}{ MCS > mean (50) } \\
\hline & $n$ & $\%$ & $p$-value & $\mathrm{n}$ & $\%$ & $\mathrm{p}$-value \\
\hline \multicolumn{7}{|l|}{ Gender } \\
\hline Male & 3,388 & 64.5 & 0.000 & 3,685 & 70.1 & \multirow{3}{*}{0.000} \\
\hline Female & 3,860 & 53.8 & & 4,118 & 57.5 & \\
\hline Total & 7,248 & 58.3 & & 7,803 & 62.8 & \\
\hline \multicolumn{7}{|l|}{ Age (years) } \\
\hline $20-39$ & 3,150 & 79.3 & 0.000 & 2,708 & 68.2 & \multirow{3}{*}{0.000} \\
\hline $40-64$ & 3,435 & 56 & & 3,789 & 61.8 & \\
\hline$\geq 65$ & 662 & 28.6 & & 1,306 & 56.3 & \\
\hline \multicolumn{7}{|l|}{ Years of study } \\
\hline Illiterate & 666 & 35 & 0.000 & 956 & 50.2 & \multirow{5}{*}{0.000} \\
\hline $1-4$ & 1,819 & 50.6 & & 2,171 & 60.4 & \\
\hline $5-8$ & 1,613 & 63.8 & & 1,635 & 64.7 & \\
\hline Secondary school & 1,791 & 74.4 & & 1,687 & 70 & \\
\hline $\begin{array}{l}\text { Higher education } \\
\text { or more }\end{array}$ & 809 & 72.9 & & 799 & 72 & \\
\hline \multicolumn{7}{|l|}{ Smoking } \\
\hline Never smoked & 4,270 & 61.7 & 0.000 & 4,457 & 64.4 & \multirow{3}{*}{0.000} \\
\hline $\begin{array}{l}\text { Used to smoke } \\
\text { and stopped }\end{array}$ & 1,526 & 49.4 & & 1,891 & 61.2 & \\
\hline Currently smoke & 1,452 & 60.2 & & 1,455 & 60.4 & \\
\hline \multicolumn{7}{|l|}{ Number of morbidities } \\
\hline Healthy & 3,767 & 82.7 & 0.000 & 3,447 & 75.7 & \multirow{4}{*}{0.000} \\
\hline 1 & 1,850 & 61 & & 1,993 & 65.6 & \\
\hline 2 & 892 & 44.7 & & 1,162 & 58.2 & \\
\hline 3 or more & 738 & 26 & & 1,201 & 42.3 & \\
\hline \multicolumn{7}{|l|}{ Occupational group } \\
\hline Group 1 & 368 & 77.4 & 0.000 & 357 & 75.3 & \multirow{6}{*}{0.000} \\
\hline Group 2 & 1,233 & 74.5 & & 1,160 & 70.1 & \\
\hline Group 3 & 466 & 72.2 & & 459 & 71.1 & \\
\hline Group 4 & 1,142 & 65.7 & & 1,124 & 64.6 & \\
\hline Group 5 & 1,198 & 72.3 & & 1,191 & 71.9 & \\
\hline Group 6 & 2,841 & 45.4 & & 3,511 & 56.1 & \\
\hline
\end{tabular}

PCS: physical quality of life; MCS: mental quality of life.

PCS: qualidade de vida física; MCS: qualidade de vida mental. 
Table 3 - Results of multivariate logistic regression model (stepwise) for above average mental and physical quality of life outcomes. Pesquisa Dimensões Sociais das Desigualdades, Brazil, 2008.

Tabela 3 - Resultados do modelo de regressão logística multivariada (stepwise) para os desfechos de qualidade de vida mental e qualidade de vida física acima da média. Pesquisa Dimensões Sociais das Desigualdades, Brasil, 2008.

\begin{tabular}{|c|c|c|c|c|}
\hline \multirow{2}{*}{$\begin{array}{l}\text { Logistic regression } \\
\text { model (stepwise) }\end{array}$} & \multirow{2}{*}{ Adjusted OR } & \multirow{2}{*}{$\begin{array}{c}\mathrm{PCS}>\text { mean }(50) \\
95 \% \mathrm{Cl}\end{array}$} & \multirow{2}{*}{ Adjusted OR } & \multirow{2}{*}{$\frac{\text { MCS > mean (50) }}{95 \% \mathrm{Cl}}$} \\
\hline & & & & \\
\hline \multicolumn{5}{|l|}{ Occupational group } \\
\hline Group 6* & 1.000 & - & 1.000 & - \\
\hline Group 1 & $1.867^{* *}$ & $1.420-2.455$ & $1.575^{* *}$ & $1.221-2.031$ \\
\hline Group 2 & $1.728^{* *}$ & $1.482-2.014$ & $1.383^{* *}$ & $1.203-1.590$ \\
\hline Group 3 & $1.942^{* *}$ & $1.574-2.397$ & $1.427^{* *}$ & $1.173-1.736$ \\
\hline Group 4 & $1.576^{* *}$ & $1.379-1.800$ & $1.173^{* *}$ & $1.035-1.330$ \\
\hline Group 5 & $1.720^{* *}$ & $1.492-1.983$ & $1.528^{* *}$ & $1.334-1.749$ \\
\hline \multicolumn{5}{|l|}{ Gender } \\
\hline Female $^{*}$ & - & - & 1.000 & - \\
\hline Male & - & - & 1.364 & $1.247-1.493$ \\
\hline \multicolumn{5}{|l|}{ Age (years) } \\
\hline 65 or more* & 1.000 & - & 1.000 & - \\
\hline $20-40$ & $2.550^{* *}$ & $2.197-2.96$ & $0.637^{* *}$ & $0.554-0.733$ \\
\hline $40-65$ & $1.614^{* *}$ & $1.425-1.829$ & $0.780^{* *}$ & $0.695-0.875$ \\
\hline \multicolumn{5}{|l|}{ Years of study } \\
\hline Illiterate* & 1.000 & - & 1.000 & - \\
\hline $1-4$ & $1.654^{* *}$ & $1.449-1.888$ & $1.497^{* *}$ & $1.329-1.686$ \\
\hline $5-8$ & $1.924^{* *}$ & $1.661-2.228$ & $1.616^{* *}$ & $1.414-1.847$ \\
\hline $9-11$ & $2.675^{* *}$ & $2.284-3.131$ & $1.841^{* *}$ & $1.596-2.125$ \\
\hline$\geq 12$ & $3.087^{* *}$ & $2.524-3.777$ & $2.136^{* *}$ & $1.774-2.572$ \\
\hline \multicolumn{5}{|c|}{ Number of morbidities } \\
\hline$\geq 3$ morbidities* & 1.000 & - & 1.000 & - \\
\hline Healthly & $9.393^{* *}$ & $8.265-10.675$ & $4.143^{* *}$ & $3.686-4.656$ \\
\hline 1 & $3.512^{* *}$ & $3.105-3.973$ & $2.537^{* *}$ & $2.262-2.845$ \\
\hline 2 & $2.111^{* *}$ & $1.848-2.412$ & $1.844^{* *}$ & $1.632-2.083$ \\
\hline \multicolumn{5}{|l|}{ Smoking } \\
\hline Currently smoke* & 1.000 & - & 1.000 & - \\
\hline Never smoked & 1.06 & $0.942-1.193$ & $1.172^{* * *}$ & $1.051-1.307$ \\
\hline $\begin{array}{l}\text { Used to smoke } \\
\text { and stopped }\end{array}$ & 0.902 & $0.791-1.029$ & $1.141^{* * *}$ & $1.01-1.289$ \\
\hline
\end{tabular}

PCS: physical quality of life; MCS: mental quality of life; OR: Odds Ratio.

${ }^{*}$ Reference category from Odds Ratio; **p $<0.001 ;{ }^{* * *} p<0.05$

PCS: qualidade de vida física; MCS: qualidade de vida mental; OR: Odds Ratio.

${ }^{*}$ Categoria de referência da Odds Ratio; ${ }^{* *} p<0,001 ;{ }^{* * *} p<0,05$ 

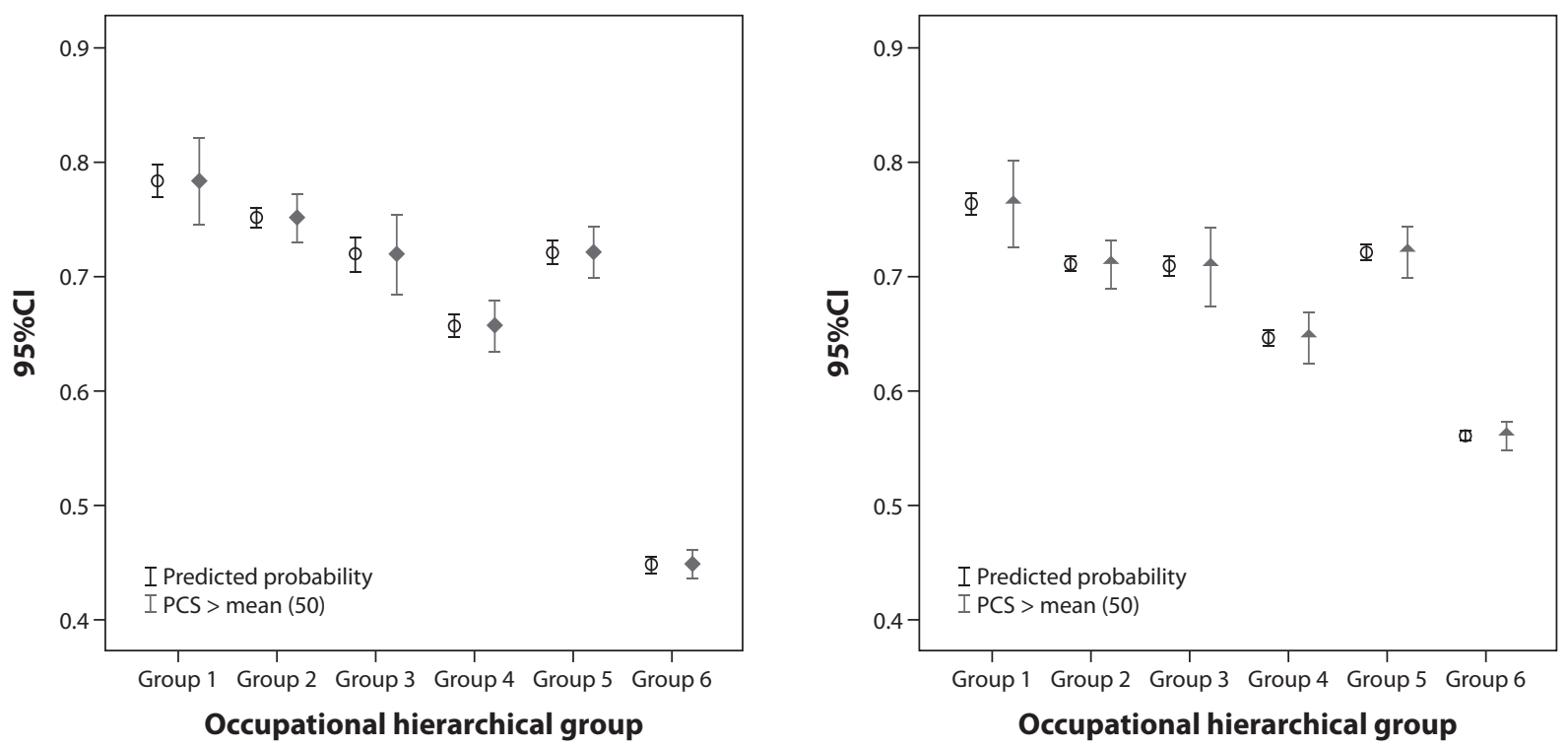

Figure 1 - Predicted probability and observed probability for physical and mental quality of life outcomes above the mean. Pesquisa Dimensões Sociais das Desigualdades, Brazil, 2008.

Figura 1 - Probabilidade predita e probabilidade observada para os desfechos de qualidade de vida física e qualidade de vida mental acima da média. Pesquisa Dimensões Sociais das Desigualdades, Brasil, 2008.

association between occupational characteristics and physical and mental health, measured by the SF-36, was also noticed in the study carried in The United Kingdom ${ }^{22}$. When observing the QoL profile, according to occupational characteristics which, in turn, reflect the social conditions to which Brazilians are submitted to, one can notice the coherence to studies seeking to evaluate the influence of social position in health ${ }^{9}$. Authors defend that the grouping of people in different social positions results in an uneven distribution of goods, services, health conditions, social advantages and disadvantages ${ }^{9,19,23}$. This occupational/ social separation, therefore, produces a set of determination groups which operate in the genesis of risks or potentialities, in turn, manifested as a health and QoL profile, which differs between these populational groups. For Braveman ${ }^{24}$, it is a rare occurrence that the most privileged stratum does not have the most elevated health level. Still, there are indications that the individual belonging to the higher stratum enjoy better health, are taller and stronger, and live for longer than those at the basis of social hierarchy ${ }^{9}$.

Considering the results of Group 6 (not economically active), studies indicate the strong relation between poor QoL/health and the fact of being out of the labor mar$k^{2} t^{25,26}$. Studies on the unemployed, parcel of Group 6, point that unemployment is associated with higher morbi-mortality and the assuming of negative habits, which can negatively influence health ${ }^{27}$. In a national survey, it was observed that being out of the market or in worse occupational conditions would have negative reflections on the search and usage of health services ${ }^{28}$.

It is also worth mentioning that health is an important control factor in unemployment and in the permanence in work. A poor physical quality of life is pointed out as capable of pulling the worker out of the market, starting a vicious circle of social disadvantages. The fall in income - added, many times, to expenses with health - leads 
to a reduction in quality and pattern of life, resulting in a lesser social position and reduced access to social health ${ }^{29,30}$.

Being out of the working market diminishes the chances of an above average QoL. In a discussion on employment and mental health, authors state that employment creates a steady income and stability, representing something significant in the life of individuals, producing a sense of social inclusion, generating recognition by the society and contributing to a better perception of one's own situation ${ }^{31}$. The way an out-of-job situation affects the mental health of both men and women could, yet, be related to the family's responsibilities associated with $\mathrm{it}^{32}$. This way, men seem to be more susceptible to a poor mental QoL when not engaged on something. As for the remaining socio-demographic and health characteristics associated with the average physical and mental QoL, some have already been studied in other works. Men have presented higher chances of a good physical QoL when compared to women. In a population-based study of elder Brazilians, women have presented lower QoL scores in all domains of the SF- $36^{21}$. In another study, using PDSD data, women presented higher chances of evaluating their health as poor or very poor, of presenting a higher number of physical aggravations and of being depressive ${ }^{20}$. Other studies have also pointed out to a worse health evaluation of health among women ${ }^{18,33}$. According to Lima et al. ${ }^{21}$, this scenario can be attributed to the fact that women have better perception of diseases and their symptoms when compared to men.

When it comes to age, younger individuals showed better chances of an improved physical QoL. In fact, it is expected that older individuals have a poorer health condition, in physical terms, as observed in other Brazilian studies ${ }^{18,20}$. Alternatively, mental health has presented opposite behavior. Individuals, 65 years of age or more, have bigger chances of an above the average MCS. In a population-based study, individuals of more advanced age have less chance of becoming depressed when compared to other age ranges, which may influence the perception of mental health ${ }^{20}$. In studies of elder people in different age ranges, no significant variable regarding mental QoL was verified.

Results referring to education are consistent with the findings of other studies. Education is related to social position and it reflects differential risks on falling sick and dying, once it is related to the usage of health services and, in addition to that, it influences family decisions on diet, body care and prevention of diseases ${ }^{34}$. This way, it is expected that the most educated ones report a better physical and mental QoL.

The SF-36 evaluates the HRQoL; therefore, characteristics of health and/or health habits tend to reflect significantly in the areas analyzed, the effect being stronger in the physical domains. Healthy individuals present much higher chances of physical QoL above the average when compared to those with health aggravations, as found in other studies ${ }^{18,20,21}$. The habit of smoking was also significant in the reduction of good physical life chances. In a Brazilian populational study, those who are declared smokers, reported more physical aggravations, evaluated their own health more poorly and presented higher chances of becoming depressive when compared to those who have never smoked ${ }^{20}$.

The results presented in this study point to a multidetermined physical and mental QoL in accordance with other findings. It was concluded that health is associated with the introduction of individuals in the social space, as well as their relations from thereon. The inequalities in health are expressed in different dimensions, reflecting aspects inherent to the social position of individuals and social groups and including characteristics related to occupations. It is worth noting, however, that dealing with a cross-sectional survey, in which the exposition and outcome variables were measured at the same moment, prevents it from determining the direction of the relation of causality among other 
variables. Studies which can capture the timing of events will be able to lead us to a better comprehension of the effects of social disadvantages, resulting in negative health profiles. Besides, the gathering retired people, unemployed and home workers in the same group may hide relevant differences in health, attributed to each one of these categories, setting up a limitation to this study.

\section{References}

1. Seidl EMF, Zannon CMLC. Qualidade de vida e saúde: aspectos conceituais e metodológicos. Cad Saúde Pública 2004; 20(2): 580-8.

2. Fleck MPA, Leal OF, Louzada S. Desenvolvimento da versão em português do instrumento de avaliação de qualidade de vida da OMS (WHOQoL-100). Rev Bras Psiquiatr 1999; 21(1): 19-28.

3. Minayo MCS, Hartz ZMA, Buss PM. Qualidade de vida e saúde: um debate necessário. Ciênc Saúde Coletiva 2000; 5(1): 7-18.

4. Wood-Dauphinee S. Assessing Quality of Life in Clinical Research: from where have we come and where are we going? J Clin Epidemiol 1999; 52(4): 355-63.

5. The WHOQoL Group. The World Health Organization Quality of Life assessment (WHOQoL): position paper from the World Health Organization. Soc Sci Med 1995; 41(10): 1403-9.

6. Gill TM, Feinstein AR. A critical appraisal of the quality of quality-of-life measurements. JAMA 1994; 272(8): 619-26.

7. Paim JS. Abordagens Teórico-conceituais em estudos de condições de vida e saúde: notas para reflexão e ação. In: Barata RB (Org). Condições de vida e situação de saúde. Rio de Janeiro: ABRASCO; 1997. p. 7-30.

8. Castellanos PL. Epidemiologia, Saúde Pública, situação de saúde e condições de vida - considerações conceituais. In: Barata RB (Org). Condições de vida e situação de saúde. Rio de Janeiro: ABRASCO; 1997. p. 31-75.

9. Marmot M, Wilkinson RG. Social determinants of health. New York: Oxford University Press; 2005.

10. Townsend P, Davidson N. Inequalities in health: the black report and the health divide. Harmondworth: Penguin Books; 1982.

11. Laguardia J, Campos MR, Travassos CM, Najar AL, Anjos LA, Vasconcellos MM. Psychometric evaluation of the SF-36 (v.2) questionnaire in a probability sample of Brazilian households: results of the survey Pesquisa Dimensões Sociais das Desigualdades (PDSD), Brazil, 2008. Health Qual Life Outcomes 2011; 9: 61.

12. Silqueira SMF. Questionário genérico SF-36 como instrumento de mensuração da qualidade de vida relacionado a saúde de pacientes hipertensos [tese de doutorado]. Ribeirão Preto: Universidade de São Paulo; 2005.

13. Ciconelli RM. Medidas de avaliação de qualidade de vida. Rev Bras Reumatol 2003; 43(2): 9-13.
14. Mendonça TMS. Avaliação prospectiva da qualidade de vida relacionada à saúde em idosos com fratura do quadril por meio de um instrumento genérico - The medical outcome study 36-item short-form health survey (SF-36) [dissertação de mestrado]. Uberlândia: Universidade Federal de Uberlândia; 2006.

15. Ribeiro CAC. Estrutura de classes, condições de vida e oportunidades de mobilidade social. In: Silva NV, Hasenbalg C. Origens e destinos: desigualdades sociais ao longo da vida. Rio de Janeiro: Topbooks; 2003.

16. Pastore J. Desigualdade e mobilidade social no Brasil. São Paulo: T.A. Queiroz/EDUSP; 1979.

17. Ganzeboom HBG, De Graaf P, Treiman DJ. A standard international socio-economic index of occupational status. Soc Sci Res 1992; 21(1): 1-56.

18. Flor LS. Mobilidade Social e Saúde: uma análise do survey "Pesquisa Dimensões Sociais das Desigualdades (PDSD)", Brasil, 2008 [dissertação de mestrado]. Rio de Janeiro: Escola Nacional de Saúde Pública da FIOCRUZ; 2012.

19. Halleröd B, Gustafsson JE. A longitudinal analysis of the relationship between changes in socio-economic status and changes in health. Soc Sci Med 2001; 72(1): 116-23.

20. Pavão ALB, Ploubidis G, Werneck G, Campos MR. Racial discrimination and health in Brazil: evidence from a population based survey. Ethn Dis 2012; 22(3): 353-9.

21. Lima MGL, Barros MBA, César CLG, Goldbaum M, Carandina L, Ciconelli RM. Health related quality of life among the eldery: a population-based study using SF-36 survey. Cad Saúde Pública 2009; 25(10): 2159-67.

22. Chandola T, Bartley M, Sacker A, Jenkinson C, Marmot M. Health selection in the Whitehall II study, UK. Soc Sci Med 2003; 56(10): 2059-72.

23. Fahel M. Desigualdades em saúde no Brasil: uma análise do acesso aos serviços de saúde por estratos ocupacionais. In: Anais do Congresso Brasileiro de Sociologia; 2007; Belo Horizonte (BR). Belo Horizonte: Sociedade Brasileira de Sociologia; 2007.

24. Braveman P. Health disparities and health equity: concepts and measurement. Annu Rev Public Health 2006; 27: 167-94.

25. Elstad JI. Health and status attainment: effects of health on occupational achievement among employed Norwegian men. Acta Sociol 2004; 47(2): 127-40. 
26. Ki M. Health selection and health inequalities [tese de doutorado]. Londres: University College London; 2009.

27. Giatti L, Barreto SM, Cesar CC. Informal work, unemployment and health in Brazilian metropolitan areas, 1998 and 2003. Cad Saúde Pública 2008; 24(10): 2396-406.

28. Giatti L, Barreto SM. Situação no mercado de trabalho e utilização de serviços de saúde no Brasil. Ciênc Saúde Coletiva 2011; 16(9): 3817-27.

29. Cardano M, Costa G, Demaria M. Social mobility and health in the Turin longitudinal study. Soc Sci Med 2004; 58(8): 1563-74.

30. Schuring M, Burdorf L, Kunst A, Mackenbach J. The effects of ill health on entering and maintaining paid employment: evidence in European countries. JEpidemiol Community Health 2007; 61(7): 597-604.
31. Pinheiro LRS, Monteiro JK. Refletindo sobre desemprego e agravos à saúde mental. Cad Psicol Soc Trab 2007; 10(2): 35-45.

32. Artazcoz L, Benach J, Borrell C, Cortès I. Unemployment and mental health: undertanding the interactions among gender, family roles, and social class. Am J Public health 2004; 94(1): 82-8.

33. Dachs JNW, Santos APR. Auto-avaliação do estado de saúde no Brasil: análise dos dados da PNAD/2003. Ciênc Saúde Coletiva 2006; 11(4): 887-94.

34. Magalhães R. Monitoramento das desigualdades sociais em saúde: significados e potencialidas das fontes de informação. Ciênc Saúde Coletiva 2007; 12(3): 667-73.

Received on: 11/29/12

Final version presented on: 03/27/13 Accepted on: 07/07/13 